\title{
Description, analogy, symbolism, faith. Jesuit science and iconography in the early modern debate on the origin of springs
}

\section{Descrizione, analogia, fede. Studio delle acque e iconografia nei trattati gesuitici d'Età Moderna}

Francesco Luzzini

University of Oklahoma - University Libraries - Norman (OK), USA

francesco_luzzini@yahoo.com; fluzzini@ou.edu

Keywords: hystory of geology; hydrogeology, Early Modern period, Jesuits.

Parole chiave: storia della geologia, idrogeologia, Età Moderna, Gesuiti

In 1521, while defending Pamplona against French and Navarrese troops, the nobleman Ignatius of Loyola was seriously injured by a cannonball aimed at his leg. He was forced to endure a long recovery and a profound spiritual experience, which eventually led him to take holy orders and to found a new congregation.

Conversion aside, Ignatius passed his fighting spirit on to his followers. Jesuits, the soldiers of God, strived to spread Catholicism around the world fighting relentlessly against heresy and Protestantism. But differently from other Catholic orders, the education imparted in Jesuit colleges - the collegi - was not limited to theology, philosophy, and rhetoric. In many cases, technical and scientific subjects were part of the study plan: an approach rooted in the belief that delving into every aspect of human knowledge would allow a better defense of Catholic orthodoxy. As a matter of fact, by the end of the sixteenth century, many colleges had become centers of excellence all over Europe for such disciplines as mathematics, astronomy, hydraulics, and mechanics; and not a few members of the order provided influential contributions to science.

As it happens when new points of view are considered, unexpected paths come into sight. And as knowledge deepens, wonder increases, and the temptation to explore these paths gets stronger and stronger. Soon, curiosity undermined the monolithic structure of the order, making it far more complex and heterogeneous than before. And in the case of the study of waters, the inquisitive eye of Jesuits took part in the long-standing debate on the origin of springs (Baldwin, 2003; Luzzini, 2015a, 2015b; Maffioli, 2010).

These attempts to harmonize religion, experimentalism, and philosophy, though carried out within the rigorous theoretical framework imposed by the Counter-Reformation, gave rise to a number of significant and ingenious interpretations of hydrogeological phenomena: and a crucial role was played by the use of iconography. Images became essential tools to ease the comprehension of refined theoretical models, made even more tortuous by the need to conform with Catholic doctrine - and, therefore, with two unescapable hurdles: the non-existence of void, and geocentrism. This approach required Jesuits to focus on the same topics handled by their enemies; and, consequently, led them to interact with the very theories they opposed.

This is the case of the French Honoré Fabri and of his Dialogi physici, clearly meant to be a polemic response to Gali- leo's Copernicanism and to Torricelli's experiments on atmospheric pressure and on vacuum. Interestingly, in discussing the cause of tides and the behavior of liquids in narrow channels, Fabri uses Torricelli's experimental premises and results to uphold a contrary interpretation: liquids are forced to rise into channels against gravity, just because they must respect the principle of horror vacui. As to the illusory empty space that can be observed in Torricelli's experiment, a mere look can discern that it is not vacuum (Fabri, 1665).

Fabri's arguments are supported by a number of detailed diagrams (Fig. 1). A similar use of iconography can be found in Cursus seu mundus mathematicus, by Claude François Milliet Dechales. In this case, however, the author accepts Galileo's theory of motion. Dechales addresses the issue of the origin of springs by evaluating the competing models of his time (Milliet Dechales, 1674): the theory supporting meteoric causes, the rise of water as a consequence of capillary action, the so-called theory of alembics (according to which hidden channels connect the oceans to the earth, allowing seawater to rise and to lose its salt by filtration or condensation), the one asserting that the average altitude of land masses is below the sea level, and the other supposing an influence of tides.

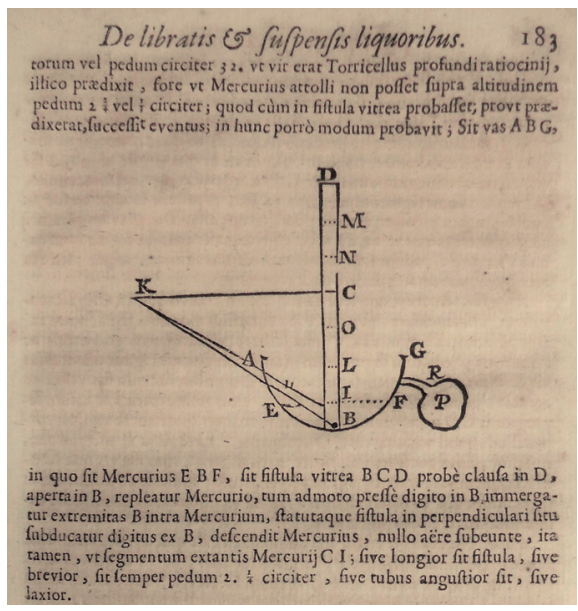

Fig. 1: De libratis et suspensis liquoribus (Fabri, 1665).

None of these options seems appealing to Dechales. He resorts to consider springs as originated by both precipitation and a subterranean heat strong enough to raise seawater, activating the hydrologic cycle. But while rains can be observed, the existence of a subterranean heat capable of transforming 
seawater into fresh water can be only supposed. Dechales is aware of the limits imposed by experimentalism on theoretical interpretation: hence the many diagrams in his treatise, whose explanatory power helps filling the gap between observation and deduction. Like in Fabri's treatise, however, these illustrations are plain and concise (Fig. 2): there is no room for symbolism, nor interest for the artistic and evocative potential of iconography. Still, other Jesuits understood and exploited these features at their best, creating some of the most beautifully illustrated treatises of their time.

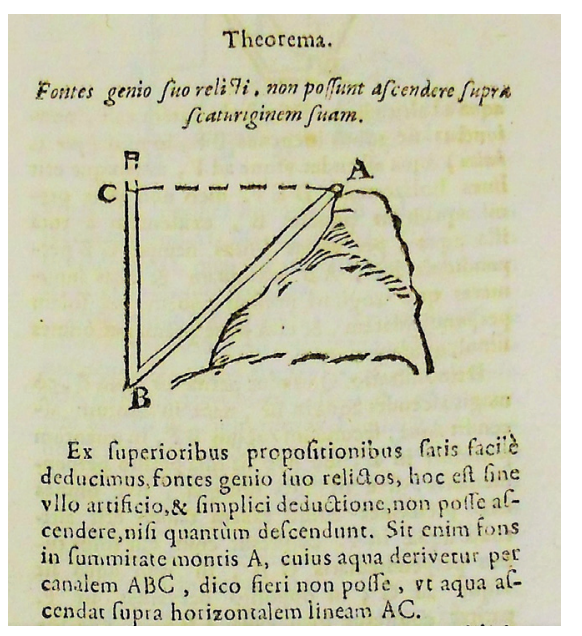

Fig. 2: Fontes genio suo relicti, non possunt ascendere supra scaturiginem suam (Milliet Dechales, 1674).

In 1642, the Italian Mario Bettini published the Apiaria universae philosophiae mathematicae. In his monumental work he privileged mathematics, intended as the only discipline abstract enough to allow intellect to approach theology. On the contrary, he considered a research based on sense as too bound to human limitations (and, therefore, unreliable). Yet, Bettini was a skilled astronomer; and clues of experimental knowledge are all but invisible in his treatise. Of course, he supported the geocentric model. And his calculations, though starting from this premise, led him to develop a coherent system on the perpetual motion of rivers.

To understand Bettini's theory, we need to focus on the principle of the Ptolemaic model, according to which the Earth is the center of the universe - and, therefore, its center of gravity. But since the distribution of lands and oceans is irregular, the center of gravity of the whole universe and the center of mass of the planet do not coincide. Thus, some zones of the planet, like the mountains, are more distant from its center of mass than others, and are less subject to gravity. And as water is not fixed, it moves perpetually, in its eternal attempt to restore equilibrium. Hence it goes from the oceans to the mountains, returns to the oceans, and so on.

This giant, perpetual motion conforms to the Holy Scriptures, and its operation can be explained by means of mechanical models: the Apiaria is illustrated with beautiful engravings of these machines (Fig. 3), which - Bettini points out - are rough imitations of the great and perfect mechanism provided by God (Bettini, 1642).

The hydrogeological debate was not ignored by two eclectic Jesuits of the $17^{\text {th }}$ century:Athanasius Kircher

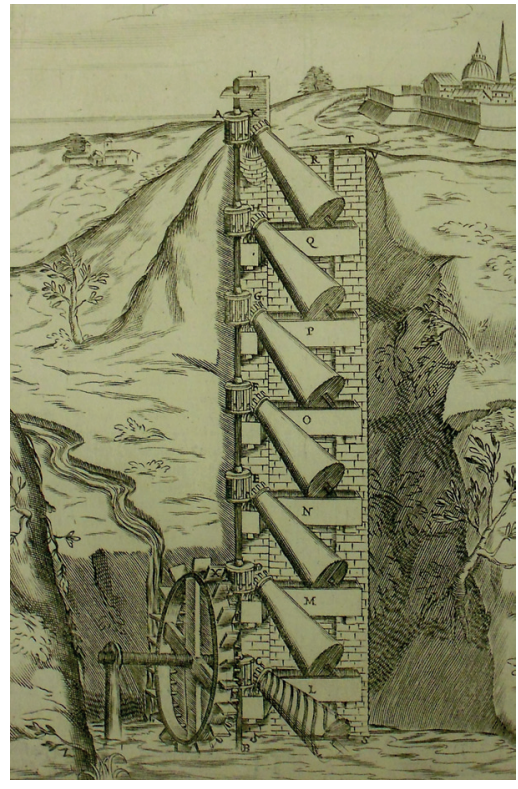

Fig. 3: One of Bettini's mechanical models.

Fig. 3: Esempio dei modelli meccanici di Bettini. and his follower, Gaspar Schott. These authors merged Aristotelian,Neoplatonic and Hermetic doctrines with field research and experimentalism, leading to intriguing results. In Kircher's Mundus subterraneus (Kircher, 1664-1665) and in Schott's Anatomia physico-hydrostatica (Schott, 1663), the Earth-or Geocosmus-is studied as a living organism. Different vital fluids run through the planet, as macroscopic counterparts of metabolic processes; and all the geological and athmospheric phenomena result from the interaction between these circulatory systems. Kircher and Schott acknowledge evaporation as a means to replenish springs. But the water networks (hydrophylacia) are the main causes: they connect the sea to the mountains, allowing the water to rise. For the enormous weight of the oceans, combined with tides and storms, are more than plausible sources of pressure.

To show how this system works, Kircher and Schott provide an astounding quantity of images, depicting both the Geocosmus and ingenious mechanical models of its operation: too many, indeed, to make a detailed description here. But one engraving from Kircher's, at least, is worth our attention (Fig. 4). Two bellows are connected to a container full of water. By activating the bellows, water is pumped in two pipes and then into another vessel, which is higher than the previous one and has a hole at its bottom. Here the analogy: the water in the first container symbolizes the oceans; the bellows represent storms and tides, which force water into subterranean channels (the pipes) and make it rise up the mountains (the second container), from where springs and rivers come. This theory agrees with the Biblical account, and offers a congruent model of the hydrologic cycle.

Eventually, the cumulative effect of philosophical debates and experimental data allowed to understand the water cycle, and the theory supporting the meteoric origin of springs gradually prevailed at the expense of rival systems (Luzzini, 2015a, 2015b; Maffioli, 2010). Nonetheless, it would be way too simplistic (and unquestionably outdated) to assume that the theories advanced by Jesuit scholars were the result of 
a reactionary approach, independent and antithetical to this process. For these theories, too, relied on a methodical field research and on first-rate technical and scientific competencies; and the evocative power of many Jesuit systems and of the images used to support them, just like the works performed by renowned experimentalists, contributed to shape hydrogeology.

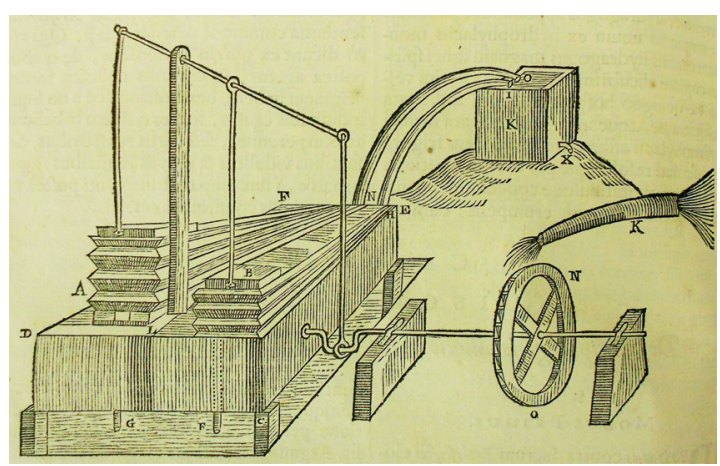

Fig. 4: Kircher's mechanical model of the bydrologic cycle.

Fig. 4: Modello meccanico di Kircher del ciclo idrologico.

\section{BIBLIOGRAFIA}

Baldwin M. (2003). Pious ambition. Natural philosophy and the Jesuit quest for the patronage of printed books. In: Feingold M. (ed.), Jesuit Science and the Republic of Letters. MIT Press, Cambridge (MA)-London.

Bettini M. (1642). Apiaria universae philosophiae mathematicae. Tomus primus. Typis Io. Baptistae Ferronij, Bononiae.

Fabri H. (1665). Dialogi physici, in quibus de motu terrae disputatur. Sumptibus Christophori Fourmy, Lugduni.

Kircher A. (1664-1665). Mundus subterraneus. Apud Ioannem Sansonium et Elizeum Weyerstraten, Amstelodami.

Luzzini F. (2015a). Through dark and mysterious paths. Earth Sciences History 2015, 2: 169- 189.

Luzzini F. (2015b). Per infera ad astra. In: Generali D. (ed.), Le radici della razionalità critica. Volume II. Mimesis, Milan-Udine.

Maffioli C.S. (2010). La via delle acque (1500-1700) "The way water (1500-1700)". Olschki, Florence.

Milliet Dechales C.F. (1674) - Cursus seu mundus mathematicus. Ex Officina Anissoniana, Lugduni.

Schott G. (1663). Anatomia physico-hydrostatica fontium ac fluminum. J. Hertz, Herbipoli. 